\title{
BOOK REVIEW: SOUTH PACIFIC PROPERTY LAW
}

\author{
A H Angelo*
}

Sue Farran and Don Paterson South Pacific Property Law (Cavendish Publishing, London, 2004) $(300+x$ li pages) NZ\$95.

The book deals with its subject-matter in 11 chapters: What is property law?, ownership, possession and occupation, special interests in property, management of property, use and enjoyment, acquisition of property, alienation of property, protection of property, resolving claims to property, and remedies in property law. The chapters are of approximately equal length.

The publisher's note says that "This book is a treasury of law relating to many different types of property in the South Pacific region ... Encompassing the legal systems of over a dozen independent countries together with cross-references to property law derived from the common law and customary law of Australia, New Zealand and North America, as well as the common law of England, the authors bring together a wealth of diverse and scattered sources to present a coherent picture of the law of property as it exists today. The book also offers some thoughts on the challenges and legal difficulties facing the region as its people and economies evolve."

From the point of view of total coverage it should be noted that of the common law jurisdictions Pitcairn is not dealt with by this book, nor are the French territories of New Caledonia, French Polynesia or Wallis and Futuna.

Property law is diverse and continually changing. There is personalty and realty, there are common law rights and equitable rights and, further, in the Pacific region customs of very great importance particularly in relation to land.

There is a paucity of accessible information about the property law in this region. The authors therefore set themselves a difficult task and it is somewhat amazing that they have managed in this text to provide a coherent and integrated commentary on the laws of the region, the defining features and the commonalities. This is the latest in a series of books on South Pacific law which has been

* Professor of Law, Victoria University of Wellington. 
produced by the staff of the Law School of the University of South Pacific. The progression is from student texts to full coverage of an area of law.

The text is clearly presented and, allowing for the occasional typographical error and some irregularity in the citation of cases, well edited.

Chapter one is the least successful chapter. The impression is of too much jargon too soon and of jargon not always used consistently. An example (one of the few where something has slipped the author's attention) is "The parties to the contract of lease are the lessor and the lessee, sometimes referred to as the landlord and tenant ... With a lease, the residual or allodial title of land remains with the leaseholder...".

As is often the case in relation to a book of broad coverage such as the present one, the authors will not have specific knowledge of all the laws. Because of the difficulty of access to the law of most Pacific jurisdictions it is therefore not surprising that there are some matters of detail that this book fails to note. Some examples may be noted in both Niue and Tokelau: there have been substantial legislative reforms in 2003 and 2004 which affected property; the government claimed radical title in both Niue and Tokelau but there is no fee simple land in Niue and only one piece of fee simple land in Tokelau; the Companies Act 1955 (NZ) is Cook Islands law only by virtue of the Companies Act $1970-71(\mathrm{CI}){ }^{2}$ it is stated that "... in all island countries of the South Pacific there is a Companies Act". ${ }^{3}$ That is not true of Niue or Tokelau, ${ }^{4}$ though the Tokelau Corporation Rules 2003 go some way to provide for that matter. Similarly it should be noted that for countries such as Samoa, Niue, Cook Islands, or Tokelau it may mislead to refer to for example the Property Law Act 1952 (NZ). Legislation in those countries may have the NZ statute as a base but in every case the current law will be different from the NZ law because of decades of local amendment. Such statutes are no longer "NZ law" - they are local law.

This is truly a treasury of property law material. It is a full text which will be of value to students of law as a point of reference, and to practitioners and teachers as a source of ideas and information and also as the starting-point for case preparation and research.

1 Sue Farran and Don Paterson South Pacific Property (Cavendish Publishing, London, 2004) 19, but see later 61.

2 Farran and Paterson, above n 1, 40.

3 Farran and Paterson, above n 1, 223.

4 Farran and Paterson, above n 1, 116 footnote 48. 